10 - ORIGINAL ARTICLE

NEW METHODOLOGY

\title{
Image analysis software versus direct anthropometry for breast measurements ${ }^{1}$
}

\author{
Paulo Rogério QuieregattoI, Bernardo Hochman", Fabianne Furtado ${ }^{\mathrm{III}}$, Aline Fernanda Perez Machado ${ }^{\mathrm{IV}}$, Miguel Sabino Netov, \\ Lydia Masako Ferreira ${ }^{\text {II }}$
}

DOI: http://dx.doi.org/10.1590/S0102-8650201400160010

IFellow Master degree, Postgraduate Program in Plastic Surgery, Federal University of Sao Paulo (UNIFESP), Brazil. Conception, design, intellectual and scientific content of the study; acquisition, interpretation and analysis of data; manuscript writing.

IIPhD, Affiliate Professor, Department of Surgery, UNIFESP, Sao Paulo-SP, Brazil. Conception, design, intellectual and scientific content of the study; interpretation and analysis of data; manuscript writing; critical revision. in memorian

IIIPhD, Affiliate Professor, Department of Surgery, UNIFESP, Sao Paulo-SP, Brazil. Conception and design of the study; acquisition, interpretation and analysis of data; manuscript writing; critical revision.

${ }^{\mathrm{IV}}$ Fellow Master degree, Postgraduate Program in Translational Surgery, UNIFESP, Sao Paulo-SP, Brazil. Interpretation and analysis of data, manuscript writing.

${ }^{\mathrm{V}} \mathrm{PhD}$, Full Professor, Department of Surgery, UNIFESP, Sao Paulo-SP, Brazil. Conception, intellectual and scientific content of the study; interpretation and analysis of data, manuscript writing, critical revision.

VIPhD, Full Professor, Division of Plastic Surgery, Department of Surgery, UNIFESP, Sao Paulo-SP, Brazil. Conception of the study, critical revision.

\section{ABSTRACT}

PURPOSE: To compare breast measurements performed using the software packages ImageTool ${ }^{\circledR}$, AutoCAD ${ }^{\circledR}$ and Adobe Photoshop ${ }^{\circledR}$ with direct anthropometric measurements.

METHODS: Points were marked on the breasts and arms of 40 volunteer women aged between 18 and 60 years. When connecting the points, seven linear segments and one angular measurement on each half of the body, and one medial segment common to both body halves were defined. The volunteers were photographed in a standardized manner. Photogrammetric measurements were performed by three independent observers using the three software packages and compared to direct anthropometric measurements made with calipers and a protractor.

RESULTS: Measurements obtained with AutoCAD ${ }^{\circledR}$ were the most reproducible and those made with ImageTool ${ }^{\circledR}$ were the most similar to direct anthropometry, while measurements with Adobe Photoshop ${ }^{\circledR}$ showed the largest differences. Except for angular measurements, significant differences were found between measurements of line segments made using the three software packages and those obtained by direct anthropometry.

CONCLUSION: AutoCAD ${ }^{\circledR}$ provided the highest precision and intermediate accuracy; ImageTool ${ }^{\circledR}$ had the highest accuracy and lowest precision; and Adobe Photoshop ${ }^{\circledR}$ showed intermediate precision and the worst accuracy among the three software packages.

Key words: Photogrammetry. Anthropometry. Software. Breast. Body Weights and Measures. 


\section{Introduction}

Because of factors such as contour, size, and volume, it is difficult to correctly measure female breasts ${ }^{1}$. Nevertheless, a thorough examination of the breast should precede any operative procedure. Knowledge of the patient's morphology is essential for the surgeon, so that the surgery can be efficiently planned ${ }^{2}$. Preoperative assessment and photographic documentation are important because they allow patients to have a better understanding about the shape and contours of their body and be informed about the limitations of the procedure, thus avoiding unrealistic expectations and minimizing doubts about the surgical results ${ }^{3}$.

Sometimes individual asymmetries go unnoticed until they are shown in an evident manner ${ }^{3}$. Besides physical examination, standardized photographic analysis is recommended, especially because of the reproducibility of measurements, which is a critical aspect of the scientific rigor required by the academic community ${ }^{4}$. Direct and indirect anthropometry can be used in the preoperative assessment of the breast to identify preexisting morphological differences. Direct anthropometry consists of linear measurements between anthropometric landmarks performed directly on the body of the patient. Quieregatto et al. ${ }^{5}$ compared direct breast anthropometric measurements taken with a tape measure with those taken using a compass. Digital or printed images are used in indirect anthropometry and measurements are made using graphic software.

Studies comparing direct and indirect anthropometry have been limited to the face and nose. Ward ${ }^{6}$ compared measurements of the nose and found no significant differences between direct and indirect anthropometry. Nechala et al. ${ }^{7}$ reported no differences in angular measurements and linear measurements of two points in the same sagittal plane between photogrammetric measurements and direct anthropometry. Sivagnanavel et al. ${ }^{8}$ and Assunção et $a l .{ }^{9}$ conducted studies to validate software packages by comparing indirect anthropometric measurements obtained with the different software, arguing that although these digital tools are based on the same theoretical principles they could generate different results.
Computerized photogrammetry of the breast could be of great value to minimize patient embarrassment and contribute to the objective analysis of postoperative results, especially after mammaplasty. However, no studies were found in the literature comparing direct and indirect anthropometric methods to assess the breast.

Thus, the aim of this study was to compare breast measurements obtained using different graphic software packages with direct anthropometric measurements.

\section{Methods}

The study was approved by the Research Ethics Committee of the Federal University of Sao Paulo (UNIFESP) and performed in accordance with the Resolution 196/96 of the Brazilian National Health Council (CNS) on research involving human beings and the ethical standards of the 1975 Declaration of Helsinki and its subsequent amendments. Written informed consent was obtained from all participants prior to their inclusion in the study, and anonymity was ensured.

The sample included 40 women volunteers, aged 18 to 60 years (mean, 29.83; SD, 10.25). Women who underwent mastectomy, volunteers with a history of breast surgery, thoracic deformities or severe breast ptosis in which the nipples crosses a transverse line at the lower limit of the umbilicus were not included in the study.

Self-adhesive circular labels $6 \mathrm{~mm}$ in diameter (model OP4433, Pimaco BIC, Rio de Janeiro, Brazil) were used to mark eight points in each half of the body, five of which were anthropometric landmarks: the center of the suprasternal notch (SN) and distal end of the xiphoid process (Xi); and bilaterally, the center of the nipple (NIP), acromion (Ac), and the anterior projection of the lateral epicondyle (EpL). Three other anatomical points were marked in both halves of the body: the point corresponding to half the distance between the center of the suprasternal notch and acromion, named $\mathrm{x}$-point of the clavicle $(\mathrm{xCl})$; the point more proximally projected of the anterior axillary line $(\mathrm{Ax})$; and the point corresponding to half the distance between the acromion and the lateral epicondyle, named midpoint of the humerus (1/2Hum) (Figure 1). 


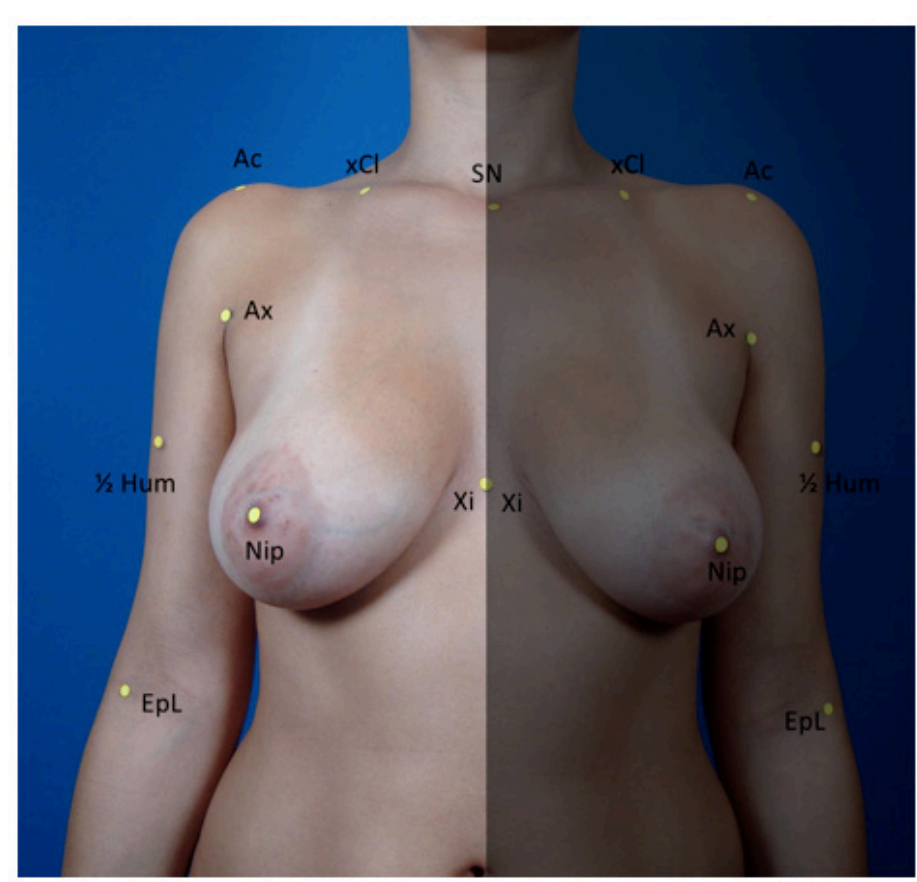

FIGURE 1 - Position of the anthropometric landmarks and anatomical points (yellow labels). Counterclockwise direction: $\mathrm{SN}$, suprasternal notch; $\mathrm{xCl}$, midpoint between the $\mathrm{SN}$ and $\mathrm{Ac}$; Ac, lateral prominence of the acromion; $\mathrm{Ax}$, point more proximally projected of the anterior axillary line; $1 / 2 \mathrm{Hum}$, midpoint between $\mathrm{Ac}$ and $\mathrm{EpL}$; EpL, anterior projection of the lateral epicondyle; NIP, center of the nipple; and Xi, distal end of the xiphoid process.

Fifteen line segments were defined by connecting specific pairs of points. One line segment was common to both halves of the body, and the other 14 were bilaterally symmetrical (seven line segments on each half of the body). A common line segment connected the suprasternal notch to the distal end of the xiphoid process (SN-Xi). The bilateral line segments were created by connecting the following pairs of points: the suprasternal notch to the center of the nipple (SN-NIP); $\mathrm{x}$-point of the clavicle to the center of the nipple (xCl-NIP); the acromion to the center of the nipple (Ac-NIP); the acromion to the lateral epicondyle (Ac-EpL); the proximal point of the anterior axillary line to the center of the nipple (Ax-NIP), the acromion to the midpoint of the humerus (Ac$1 / 2 \mathrm{Hum})$, and the center of the nipple connected perpendicularly to the anterior midline (NIP-ML) (Figure 2).

The sternal angles (SA), on both the right and left halves of the body, are formed by the bilateral segments SN-NIP and the midline $\mathrm{SN}-\mathrm{Xi}$ (Figure 2). These angles were measured with a protractor.

Indirect anthropometric measurements were made by three independent investigators for assessment of inter-rater reliability, and the principal investigator repeated the measurements with all graphics software packages to investigate the intra-rater reliability of each package. The investigators received specific training in the use of the graphic software packages UTHSCSA
ImageTool $^{\circledR} 3.0$ (University of Texas Health Science Center, San Antonio, USA; free download at: http://compdent.uthscsa.edu/ ITDownload.asp), Adobe Photoshop CS4 ${ }^{\circledR}$ (Adobe Systems Inc.), and AutoCAD ${ }^{\circledR} 2008$ (Autodesk).

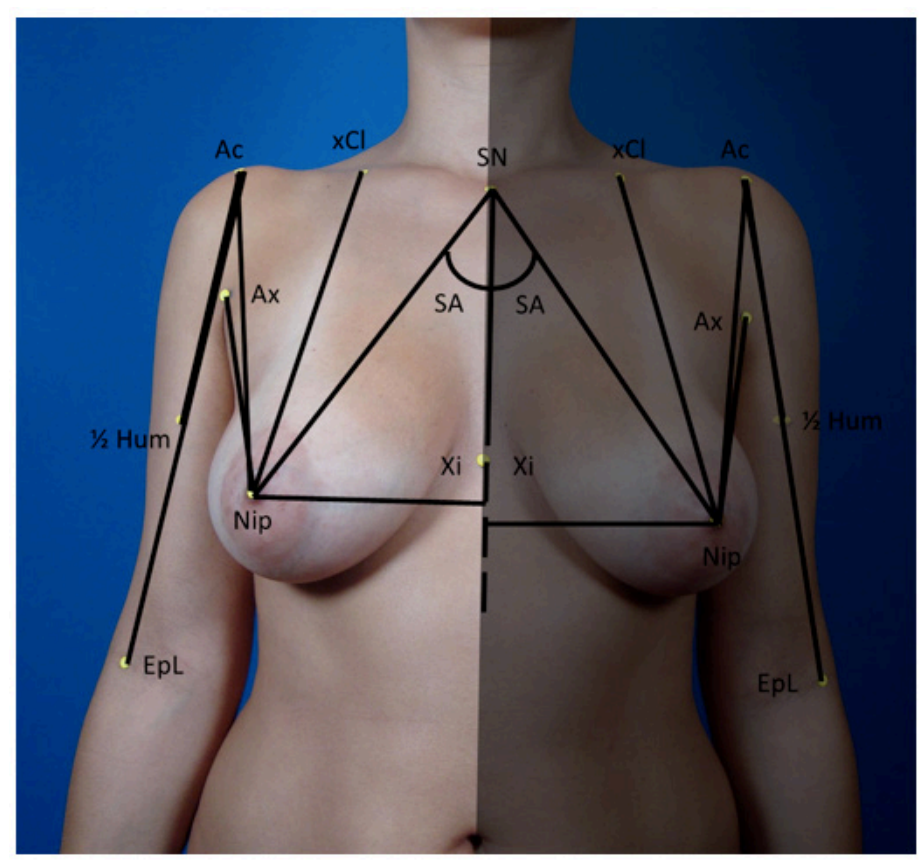

FIGURE 2 - Line segments and angles used for the direct and indirect anthropometric measurements. Line segments: $\mathrm{SN}-\mathrm{Xi}$, suprasternal notch to the xiphoid process; SN-NIP, suprasternal notch to the nipple; $x C l-N I P$, $\mathrm{x}$-point of the clavicle to the nipple; Ac-NIP, acromion to the nipple; AxNIP, proximal point of the anterior axillary line to the nipple; NIP-ML, from the center of the nipple perpendicular to the midline; Ac-EpL, acromion to the lateral epicondyle; Ac-1/2Hum, acromion to the midpoint of the humerus. SA, sternal angle formed by the bilateral line segments SN-NIP.

The volunteers were photographed standing at the same position marked on the floor by vinyl foam in a specially prepared room. The position of the camera and light sources, and light exposure were the same for all photographs. The software packages were calibrated for length by measuring a 1-cm segment on a millimeter ruler that was included in each picture attached to the right mesogastric region of each volunteer.

Direct anthropometric measurements of the line segments were performed by first placing the tips of a caliper onto the endpoints of the line segments and then measuring the distance between tips with a ruler; angular measurements were performed with a protractor.

The intraclass correlation coefficients (ICCs) and respective $95 \%$ confidence intervals $(95 \% \mathrm{CI}$ ) were used to evaluate inter- and intra-rater reliability, and reproducibility of line segment measurements.

The absolute differences between direct anthropometric measurements and digital measurements performed with each 
software package were also calculated. These differences were described using mean, standard deviation, median, minimum and maximum values. Following, these values were compared using analysis of variance (ANOVA). Bonferroni's multiple comparison test was used with variables showing significant differences $(\mathrm{p}<0.05)$. All statistical tests were performed at a significance level of $0.05(\mathrm{p}<0.05)$.

\section{Results}

In the intra-rater reliability analysis, measurements performed with AutoCAD ${ }^{\circledR}$ had the highest ICC values, followed by those made with Adobe Photoshop ${ }^{\circledR}$ and ImageTool ${ }^{\circledR}$ (Table 1).

TABLE 1 - Intra-rater reliability for the different line segments measured with the graphic software packages.

\begin{tabular}{|c|c|c|c|c|c|c|}
\hline \multicolumn{7}{|c|}{ Intra-rater reliability } \\
\hline \multirow[t]{2}{*}{ Software } & \multirow[t]{2}{*}{ Variable } & \multirow[t]{2}{*}{ ICC } & \multicolumn{2}{|c|}{$95 \% \mathrm{CI}$} & \multicolumn{2}{|c|}{$\begin{array}{l}\text { Absolute } \\
\text { difference }\end{array}$} \\
\hline & & & Lower & Upper & Mean & SD \\
\hline \multirow[t]{9}{*}{ ImageTool $^{\circledR}$} & $\mathrm{SN}-\mathrm{Xi}$ & 0.842 & 0.745 & 0.901 & 0.84 & 0.55 \\
\hline & SN-NIP & 0.861 & 0.772 & 0.914 & 1.20 & 0.80 \\
\hline & xCl-NIP & 0.905 & 0.840 & 0.941 & 1.02 & 0.73 \\
\hline & Ac-NIP & 0.922 & 0.864 & 0.953 & 0.93 & 0.64 \\
\hline & Ax-NIP & 0.960 & 0.930 & 0.976 & 0.57 & 0.42 \\
\hline & NIP-ML & 0.803 & 0.696 & 0.873 & 0.71 & 0.49 \\
\hline & Ac-EpL & 0.634 & 0.454 & 0.759 & 1.58 & 1.03 \\
\hline & Ac-1/2Hum & 0.574 & 0.389 & 0.711 & 0.82 & 0.64 \\
\hline & SA angle & 0.997 & 0.995 & 0.998 & 0.27 & 0.24 \\
\hline \multirow[t]{9}{*}{ AutoCAD ${ }^{\circledR}$} & $\mathrm{SN}-\mathrm{Xi}$ & 0.975 & 0.959 & 0.984 & 0.22 & 0.26 \\
\hline & SN-NIP & 0.987 & 0.978 & 0.992 & 0.29 & 0.28 \\
\hline & xCl-NIP & 0.988 & 0.980 & 0.992 & 0.27 & 0.33 \\
\hline & Ac-NIP & 0.995 & 0.991 & 0.997 & 0.22 & 0.18 \\
\hline & Ax-NIP & 0.997 & 0.995 & 0.998 & 0.13 & 0.15 \\
\hline & NIP-ML & 0.958 & 0.935 & 0.973 & 0.23 & 0.27 \\
\hline & Ac-EpL & 0.940 & 0.902 & 0.963 & 0.40 & 0.41 \\
\hline & Ac-1/2Hum & 0.911 & 0.863 & 0.943 & 0.24 & 0.26 \\
\hline & SA angle & 0.988 & 0.981 & 0.992 & 0.32 & 0.65 \\
\hline \multirow{9}{*}{$\begin{array}{l}\text { Adobe } \\
\text { Photoshop }^{\circledR}\end{array}$} & $\mathrm{SN}-\mathrm{Xi}$ & 0.937 & 0.904 & 0.959 & 0.40 & 0.39 \\
\hline & SN-NIP & 0.946 & 0.917 & 0.965 & 0.56 & 0.55 \\
\hline & xCl-NIP & 0.967 & 0.949 & 0.979 & 0.47 & 0.46 \\
\hline & Ac-NIP & 0.971 & 0.956 & 0.982 & 0.44 & 0.45 \\
\hline & Ax-NIP & 0.986 & 0.978 & 0.991 & 0.27 & 0.28 \\
\hline & NIP-ML & 0.924 & 0.884 & 0.951 & 0.34 & 0.32 \\
\hline & Ac-EpL & 0.832 & 0.750 & 0.889 & 0.73 & 0.74 \\
\hline & Ac-1/2Hum & 0.799 & 0.703 & 0.866 & 0.40 & 0.42 \\
\hline & SA angle & 0.998 & 0.997 & 0.999 & 0.22 & 0.20 \\
\hline
\end{tabular}

ICC, intraclass correlation coefficient; $\mathrm{Cl}$, confidence interval, SD, standard deviation; $\mathrm{SN}$, suprasternal notch; $\mathrm{xCl}, \mathrm{x}$-point of the clavicle; Ac, acromion; Ax, proximal point of the anterior axillary line; ML, midline; 1/2Hum, midpoint of the humerus; EpL, lateral epicondyle; NIP, center of the nipple; Xi, xiphoid process; SA, sternal angle.
Results of the inter-rater reliability analysis are shown in Table 2. Just as in the intra-rater analysis, measurements performed with AutoCAD ${ }^{\circledR}$ had the highest ICC values. Measurements made with ImageTool ${ }^{\circledR}$ and Photoshop ${ }^{\circledR}$ showed similar ICC values.

TABLE 2 - Inter-rater reliability for the different line segments measured with the graphic software packages.

\begin{tabular}{|c|c|c|c|c|c|c|}
\hline \multicolumn{7}{|c|}{ Inter-rater reliability } \\
\hline \multirow[t]{2}{*}{ Software } & \multirow[t]{2}{*}{ Variable } & \multirow[t]{2}{*}{ ICC } & \multicolumn{2}{|c|}{$95 \% \mathrm{CI}$} & \multicolumn{2}{|c|}{$\begin{array}{l}\text { Absolute } \\
\text { difference }\end{array}$} \\
\hline & & & Lower & Upper & Mean & SD \\
\hline \multirow[t]{9}{*}{ ImageTool $^{\circledR}$} & $\mathrm{SN}-\mathrm{Xi}$ & 0.667 & 0.546 & 0.765 & 0.92 & 0.53 \\
\hline & SN-NIP & 0.717 & 0.584 & 0.811 & 1.37 & 0.86 \\
\hline & xCl-NIP & 0.800 & 0.702 & 0.868 & 1.17 & 0.73 \\
\hline & Ac-NIP & 0.829 & 0.742 & 0.888 & 1.07 & 0.69 \\
\hline & Ax-NIP & 0.902 & 0.849 & 0.937 & 0.67 & 0.49 \\
\hline & NIP-ML & 0.631 & 0.488 & 0.743 & 0.82 & 0.52 \\
\hline & Ac-EpL & 0.304 & 0.162 & 0.449 & 1.79 & 1.04 \\
\hline & Ac-1/2Hum & 0.314 & 0.168 & 0.462 & 0.89 & 0.52 \\
\hline & SA angle & 0.994 & 0.991 & 0.996 & 0.32 & 0.19 \\
\hline \multirow[t]{9}{*}{ AutoCAD ${ }^{\circledR}$} & $\mathrm{SN}-\mathrm{Xi}$ & 0.834 & 0.771 & 0.884 & 0.20 & 0.65 \\
\hline & SN-NIP & 0.921 & 0.888 & 0.946 & 0.26 & 0.66 \\
\hline & xCl-NIP & 0.992 & 0.988 & 0.994 & 0.18 & 0.17 \\
\hline & Ac-NIP & 0.984 & 0.977 & 0.989 & 0.18 & 0.30 \\
\hline & Ax-NIP & 0.980 & 0.971 & 0.986 & 0.15 & 0.32 \\
\hline & NIP-ML & 0.970 & 0.957 & 0.980 & 0.15 & 0.15 \\
\hline & Ac-EpL & 0.963 & 0.947 & 0.975 & 0.25 & 0.20 \\
\hline & Ac-1/2Hum & 0.927 & 0.896 & 0.950 & 0.15 & 0.17 \\
\hline & SA angle & 0.990 & 0.984 & 0.993 & 0.29 & 0.39 \\
\hline \multirow{9}{*}{$\begin{array}{l}\text { Adobe } \\
\text { Photoshop }^{\circledR}\end{array}$} & $\mathrm{SN}-\mathrm{Xi}$ & 0.548 & 0.108 & 0.774 & 1.10 & 0.59 \\
\hline & SN-NIP & 0.621 & 0.156 & 0.822 & 1.54 & 0.86 \\
\hline & xCl-NIP & 0.718 & 0.245 & 0.878 & 1.33 & 0.77 \\
\hline & Ac-NIP & 0.761 & 0.298 & 0.899 & 1.21 & 0.70 \\
\hline & Ax-NIP & 0.875 & 0.539 & 0.950 & 0.72 & 0.47 \\
\hline & NIP-ML & 0.540 & 0.101 & 0.770 & 0.92 & 0.48 \\
\hline & Ac-EpL & 0.181 & -0.003 & 0.379 & 2.09 & 1.10 \\
\hline & Ac-1/2Hum & 0.222 & 0.000 & 0.447 & 1.02 & 0.55 \\
\hline & SA angle & 0.927 & 0.897 & 0.950 & 0.58 & 1.13 \\
\hline
\end{tabular}

ICC, intraclass correlation coefficient; CI, confidence interval, SD, standard deviation; $\mathrm{SN}$, suprasternal notch; $\mathrm{xCl}$, $\mathrm{x}$-point of the clavicle; $\mathrm{Ac}$, acromion; $\mathrm{Ax}$, proximal point of the anterior axillary line; ML, midline; $1 / 2 \mathrm{Hum}$, midpoint of the humerus; EpL, lateral epicondyle; NIP, center of the nipple; $\mathrm{Xi}$, xiphoid process; $\mathrm{SA}$, sternal angle.

Measurements of the segments Ac-1/2Hum (ICC, 0.68) and Ac-EpL (ICC, 0.71) showed the lowest reproducibility. For all other line segments, the ICC values were higher than 0.85 (Table 3 ). 
TABLE 3 - Reproducibility of line segment measurements when the different measurement methods were considered.

\begin{tabular}{lccccc}
\hline \multicolumn{3}{c}{ Reproducibility of line-segment measurements } \\
\hline Variable & ICC & \multicolumn{9}{c}{$\mathbf{9 5 \%}$ CI } & \multicolumn{2}{c}{$\begin{array}{c}\text { Absolute } \\
\text { difference }\end{array}$} \\
\cline { 3 - 6 } & & Lower & Upper & Mean & SD \\
\hline SN-Xi & 0.889 & 0.742 & 0.944 & 0.48 & 0.26 \\
SN-NIP & 0.902 & 0.774 & 0.950 & 0.68 & 0.40 \\
xCl-NIP & 0.930 & 0.822 & 0.965 & 0.60 & 0.38 \\
Ac-NIP & 0.943 & 0.843 & 0.973 & 0.55 & 0.34 \\
Ax-NIP & 0.970 & 0.922 & 0.986 & 0.35 & 0.23 \\
NIP-ML & 0.858 & 0.704 & 0.924 & 0.41 & 0.25 \\
Ac-EpL & 0.712 & 0.451 & 0.841 & 0.90 & 0.49 \\
Ac-1/2Hum & 0.683 & 0.433 & 0.817 & 0.46 & 0.29 \\
SA angle & 0.991 & 0.986 & 0.994 & 0.28 & 0.36 \\
\hline
\end{tabular}

ICC, intraclass correlation coefficient; $\mathrm{CI}$, confidence interval, SD, standard deviation; $\mathrm{SN}$, suprasternal notch; $\mathrm{xCl}$, $\mathrm{x}$-point of the clavicle; $\mathrm{Ac}$, acromion; $\mathrm{Ax}$, proximal point of the anterior axillary line; ML, midline; $1 / 2 \mathrm{Hum}$, midpoint of the humerus; EpL, lateral epicondyle; NIP, center of the nipple; Xi, xiphoid process; SA, sternal angle.
The measurements of almost all line segments obtained using the software packages showed significant differences when compared with direct anthropometric measurements, except for measurements of the sternal angle (Table 4). Measurements obtained with ImageTool ${ }^{\circledR}$ were the most similar to direct anthropometric measurements, whereas the largest differences were found when Adobe Photoshop ${ }^{\circledR}$ and direct anthropometric measurements were compared.

There were no significant differences in the segment NIPML measurements between direct anthropometric measurements and those made with ImageTool ${ }^{\circledR}$ and $\operatorname{AutoCAD}^{\circledR}(P=0.686)$, as shown in Table 5.

TABLE 4 - Comparison of line-segment measurements performed with the different software packages and direct anthropometry.

\begin{tabular}{|c|c|c|c|c|c|c|c|}
\hline Variable & Software & Mean & SD & Median & Minimum & Maximum & P-value \\
\hline \multirow[t]{3}{*}{ SN-Xi } & ImageTool $^{\circledR}$ & 3.45 & 1.24 & 3.53 & 1.30 & 5.70 & $<0.001$ \\
\hline & AutoCAD ${ }^{\circledR}$ & 3.77 & 1.06 & 3.60 & 1.90 & 6.10 & \\
\hline & Photoshop $^{\circledR}$ & 4.14 & 1.19 & 4.15 & 1.10 & 6.24 & \\
\hline \multirow[t]{3}{*}{ SN-NIP } & ImageTool ${ }^{\circledR}$ & 3.87 & 1.65 & 3.60 & 0.10 & 8.40 & $<0.001$ \\
\hline & AutoCAD ${ }^{\circledR}$ & 4.31 & 1.49 & 4.20 & 0.60 & 9.50 & \\
\hline & Photoshop $^{\circledR}$ & 4.84 & 1.69 & 4.62 & 1.23 & 9.59 & \\
\hline \multirow[t]{3}{*}{ xCl-NIP } & ImageTool ${ }^{\circledR}$ & 5.81 & 2.05 & 5.53 & 2.35 & 12.75 & $<0.001$ \\
\hline & AutoCAD ${ }^{\circledR}$ & 6.22 & 1.97 & 6.00 & 3.40 & 13.70 & \\
\hline & Photoshop $^{\circledR}$ & 6.72 & 2.09 & 6.48 & 2.77 & 13.87 & \\
\hline \multirow[t]{3}{*}{ Ac-NIP } & ImageTool $^{\circledR}$ & 7.72 & 2.19 & 7.60 & 3.15 & 14.25 & $<0.001$ \\
\hline & AutoCAD ${ }^{\circledR}$ & 8.12 & 2.18 & 8.00 & 3.80 & 15.30 & \\
\hline & Photoshop $^{\circledR}$ & 8.56 & 2.25 & 8.38 & 3.13 & 15.44 & \\
\hline \multirow[t]{3}{*}{ Ax-NIP } & ImageTool ${ }^{\circledR}$ & 5.88 & 1.95 & 5.65 & 2.15 & 11.70 & $<0.001$ \\
\hline & AutoCAD ${ }^{\circledR}$ & 6.16 & 1.98 & 5.90 & 2.70 & 12.30 & \\
\hline & Photoshop $^{\circledR}$ & 6.40 & 2.00 & 6.20 & 2.38 & 12.36 & \\
\hline \multirow[t]{3}{*}{ NIP-ML } & ImageTool ${ }^{\circledR}$ & 0.62 & 0.42 & 0.55 & 0.00 & 1.75 & $<0.001$ \\
\hline & AutoCAD ${ }^{\circledR}$ & 0.56 & 0.42 & 0.50 & 0.00 & 1.80 & \\
\hline & Photoshop $^{\circledR}$ & 0.86 & 0.52 & 0.78 & 0.01 & 2.83 & \\
\hline \multirow[t]{3}{*}{ Ac-EpL } & ImageTool ${ }^{\circledR}$ & 4.59 & 1.39 & 4.50 & 0.85 & 7.70 & $<0.001$ \\
\hline & AutoCAD ${ }^{\circledR}$ & 5.18 & 1.20 & 5.20 & 2.80 & 8.20 & \\
\hline & Photoshop $^{\circledR}$ & 5.89 & 1.46 & 5.92 & 2.45 & 9.69 & \\
\hline \multirow[t]{3}{*}{ Ac- $1 / 2$ Hum } & ImageTool ${ }^{\circledR}$ & 2.27 & 0.78 & 2.30 & 0.10 & 4.75 & $<0.001$ \\
\hline & AutoCAD ${ }^{\circledR}$ & 2.59 & 0.64 & 2.55 & 1.40 & 4.70 & \\
\hline & Photoshop $^{\circledR}$ & 2.94 & 0.76 & 2.96 & 1.28 & 4.94 & \\
\hline \multirow[t]{3}{*}{ SA angle } & ImageTool $^{\circledR}$ & 8.03 & 3.64 & 8.00 & 1.00 & 19.40 & 0.256 \\
\hline & AutoCAD ${ }^{\circledR}$ & 8.02 & 3.66 & 7.72 & 0.59 & 18.98 & \\
\hline & Photoshop $^{\circledR}$ & 7.92 & 3.67 & 7.75 & 0.80 & 18.80 & \\
\hline
\end{tabular}

SD, standard deviation; SN, suprasternal notch; $\mathrm{xCl}$, x-point of the clavicle; Ac, acromion; Ax, proximal point of the anterior axillary line; ML, midline; 1/2Hum, midpoint of the humerus; EpL, lateral epicondyle; NIP, center of the nipple; Xi, xiphoid process; SA, sternal angle. 
TABLE 5 - Multiple comparisons of estimated mean differences between measurements made with the software packages and direct anthropometry.

\begin{tabular}{|c|c|c|c|c|c|c|}
\hline \multirow[t]{2}{*}{ Variable } & \multirow[t]{2}{*}{ Comparison } & \multirow{2}{*}{$\begin{array}{c}\text { Estimated mean } \\
\text { difference }\end{array}$} & \multirow[t]{2}{*}{ SE } & \multirow[t]{2}{*}{ P-value } & \multicolumn{2}{|c|}{$95 \% \mathrm{CI}$} \\
\hline & & & & & Lower & Upper \\
\hline \multirow[t]{3}{*}{$\mathrm{SN}-\mathrm{Xi}$} & ImageTool $^{\circledR}$ - AutoCAD $^{\circledR}$ & -0.32 & 0.05 & $<0.001$ & -0.44 & -0.20 \\
\hline & ImageTool $^{\circledR}$ - Photoshop $^{\circledR}$ & -0.68 & 0.08 & $<0.001$ & -0.88 & -0.48 \\
\hline & AutoCAD ${ }^{\circledR}$ - Photoshop $^{\circledR}$ & -0.36 & 0.07 & $<0.001$ & -0.53 & -0.20 \\
\hline \multirow[t]{3}{*}{ SN-NIP } & ImageTool $^{\circledR}$ - AutoCAD ${ }^{\circledR}$ & -0.44 & 0.08 & $<0.001$ & -0.64 & -0.25 \\
\hline & ImageTool $^{\circledR}$ - Photoshop $^{\circledR}$ & -0.97 & 0.12 & $<0.001$ & -1.27 & -0.67 \\
\hline & AutoCAD $^{\circledR}$ - Photoshop $^{\circledR}$ & -0.53 & 0.09 & $<0.001$ & -0.75 & -0.31 \\
\hline \multirow[t]{3}{*}{ xCl-NIP } & ImageTool $^{\circledR}$ - AutoCAD ${ }^{\circledR}$ & -0.41 & 0.07 & $<0.001$ & -0.57 & -0.24 \\
\hline & ImageTool $^{\circledR}$ - Photoshop $^{\circledR}$ & -0.90 & 0.11 & $<0.001$ & -1.17 & -0.64 \\
\hline & AutoCAD $^{\circledR}$ - Photoshop $^{\circledR}$ & -0.50 & 0.08 & $<0.001$ & -0.69 & -0.30 \\
\hline \multirow[t]{3}{*}{ Ac-NIP } & ImageTool ${ }^{\circledR}$ - $\quad$ AutoCAD ${ }^{\circledR}$ & -0.40 & 0.06 & $<0.001$ & -0.55 & -0.25 \\
\hline & ImageTool $^{\circledR}$ - Photoshop $^{\circledR}$ & -0.84 & 0.10 & $<0.001$ & -1.08 & -0.61 \\
\hline & AutoCAD $^{\circledR}$ - Photoshop $^{\circledR}$ & -0.45 & 0.07 & $<0.001$ & -0.62 & -0.28 \\
\hline \multirow[t]{3}{*}{ Ax-NIP } & ImageTool ${ }^{\circledR}$ - AutoCAD ${ }^{\circledR}$ & -0.28 & 0.04 & $<0.001$ & -0.38 & -0.18 \\
\hline & ImageTool $^{\circledR}$ - Photoshop $^{\circledR}$ & -0.53 & 0.06 & $<0.001$ & -0.68 & -0.37 \\
\hline & AutoCAD $^{\circledR}$ - Photoshop $^{\circledR}$ & -0.25 & 0.05 & $<0.001$ & -0.36 & -0.13 \\
\hline \multirow[t]{3}{*}{ NIP-ML } & ImageTool ${ }^{\circledR}$ - AutoCAD ${ }^{\circledR}$ & 0.06 & 0.05 & 0.686 & -0.06 & 0.18 \\
\hline & ImageTool $^{\circledR}$ - Photoshop $^{\circledR}$ & -0.23 & 0.07 & 0.003 & -0.40 & -0.07 \\
\hline & AutoCAD ${ }^{\circledR}$ - Photoshop $^{\circledR}$ & -0.29 & 0.05 & $<0.001$ & -0.42 & -0.16 \\
\hline \multirow[t]{3}{*}{ Ac-EpL } & ImageTool $^{\circledR}$ - $\quad$ AutoCAD ${ }^{\circledR}$ & -0.59 & 0.10 & $<0.001$ & -0.84 & -0.34 \\
\hline & ImageTool $^{\circledR}$ - Photoshop $^{\circledR}$ & -1.30 & 0.15 & $<0.001$ & -1.67 & -0.92 \\
\hline & AutoCAD $^{\circledR}$ - Photoshop $^{\circledR}$ & -0.71 & 0.12 & $<0.001$ & -0.99 & -0.43 \\
\hline \multirow[t]{3}{*}{ Ac-1/2Hum } & ImageTool $^{\circledR}$ - AutoCAD ${ }^{\circledR}$ & -0.32 & 0.06 & $<0.001$ & -0.46 & -0.17 \\
\hline & ImageTool ${ }^{\circledR}$ - Photoshop $^{\circledR}$ & -0.67 & 0.08 & $<0.001$ & -0.88 & -0.46 \\
\hline & AutoCAD ${ }^{\circledR}$ - Photoshop $^{\circledR}$ & -0.35 & 0.06 & $<0.001$ & -0.50 & -0.21 \\
\hline
\end{tabular}

Bonferroni's test $(\mathrm{p}<0.05)$

$\mathrm{Cl}$, confidence interval, $\mathrm{SE}$, standard error; $\mathrm{SN}$, suprasternal notch; $\mathrm{xCl}$, $\mathrm{x}$-point of the clavicle; $\mathrm{Ac}$, acromion; $\mathrm{Ax}$, proximal point of the anterior axillary line; ML, midline; 1/2Hum, midpoint of the humerus; EpL, lateral epicondyle; NIP, center of the nipple; $\mathrm{Xi}$, xiphoid process.

\section{Discussion}

The origins of physical anthropometry can be found on reports of the travels of Marco Polo (1273-1295), in which marked differences in body size and height of people of different ethnicities were recorded. The first measurements of breasts by direct anthropometry were performed by Penn ${ }^{10}$ on 20 women, who had breasts considered aesthetically perfect by the author, with the goal of finding a standard type of the breast. Following Penn ${ }^{10}$, other authors have carried out studies to develop protocols for measuring the breast using direct anthropometry ${ }^{7,11-15}$. Odo et $a l .{ }^{16}$ evaluated pre- and postoperative breast asymmetry by direct anthropometry and reported that this method is suitable for assessing breast asymmetry. Pozzobon et al. ${ }^{17}$ used magnetic resonance imaging (MRI) and linear measurements of the breast in comparative studies of surgical procedures to correct breast asymmetry. The authors suggested that MRI associated with linear measurements constitute a good method for evaluating breast measures. As there is no consensus in the literature on which anatomical points should be used for measuring the breast or which is the ideal measurement tool, this study was conducted to compare different methods to improve the accuracy of breast measurements.

Direct anthropometry allows the quantification of differences in the breast using predetermined reference points for linear and angular measurements, for example, with the use of a ruler, tape measure, protractor and calipers ${ }^{11-15}$. Direct measurements in the thoracic region may be of relative accuracy due to the contour of the body (i.e., curves, prominences and depressions) and movements of the thoracic wall during breathing, which may vary in the same individual at different moments ${ }^{7,14}$. In order to minimize the effects of breathing, Agbenorku et al. ${ }^{18}$ proposed the use the lowest value of two successive measurements taken with a tape measure in the breast region. In this way, the obtained measurements are closer to actual body dimensions. Quieregatto et $a l .{ }^{5}$ found significant differences between measurement taken with a tape measure and those taken with a compass at the same landmarks in the breast region. 
Linear measurements obtained by photogrammetry have proven to be an effective method to assess breast symmetry ${ }^{19}$. According to Nechala et al. ${ }^{7}$, indirect anthropometry have advantages over direct anthropometry, including reduced measurement errors, millimeter accuracy, the possibility of making measurements over time and the comparison of preand postoperative measurements, reduced patient exposure to embarrassing situations, and decreased time of patient exposure during measurement. Indirect anthropometry is faster and more efficient than direct anthropometry because photogrammetric measurements can be made immediately after the picture is taken or any time later, no specific technical training is need, and has a low cost compared to 3D scanners.

Although there is a correspondence between direct and indirect anthropometry for some body regions, including the head, face, eyes, nose, mouth, and ears ${ }^{7}$, this correspondence has not been demonstrated for the breast region. There is no formula to date to calculate the actual breast dimensions using indirect anthropometry. Mallucci and Brandford ${ }^{20}$ analyzed the ratio between the upper and lower pole of the breast, and the linear and angular positions of the nipples to determine the aspect ratio of quadrants and aesthetic standards of the breast. The authors reported that these parameters are easily and objectively identified, without taking only the nipples as the main landmarks in the evaluation of the breast. The software used in that study (Adobe Photoshop $\mathrm{CS} 4^{\circledR}$ ) was considered suitable for measuring proportions and angles of the breast. However, in the present study, although angular measurements obtained with Adobe Photoshop CS4 ${ }^{\circledR}$ were the most precise, linear measurements were less precise and less accurate than those obtained with AutoCAD and ImageTool ${ }^{\circledR}$.

Measurements of the line segments AC- $1 / 2$ Hum and ACEpL were those with lower reproducibility. According to Kouchi et $a l .^{21}$, measurements of less than $10 \mathrm{~cm}$ tend not to have significant differences between repeated measurements and to be more precise those of longer line segments. This may explain the low reproducibility of measurements, since the line segments used in the present study were longer than $10 \mathrm{~cm}$. Significant differences between measurements made with the graphic software packages and direct measurement were found for most of the line segments. Measurements made with ImageTool ${ }^{\circledR}$ were the most similar to direct anthropometry, but showed low reproducibility. AutoCAD ${ }^{\mathbb{R}}$ yielded the most reproducible measurements, but showed the largest differences compared to direct anthropometry, except for angular measurements. Measurements with Adobe Photoshop $\mathrm{CS} 4{ }^{\circledR}$ were the least accurate, with intermediate precision when compared with the other two software packages. This indicates that different software tools produce different results, as suggested by Sivagnanavel et al. ${ }^{8}$ and Assunção et al. ${ }^{9}$.

Most linear measurements obtained with AutoCAD ${ }^{\mathbb{R}}$ had greater intra-rater reliability then those obtained with other software. For some line segments, ICC values were very similar for the three software packages. The mean absolute differences for each line segment were smaller for measurements made with AutoCAD ${ }^{\circledR}$, followed by those obtained with Adobe Photoshop ${ }^{\circledR}$ and ImageTool ${ }^{\circledR}$. The majority of the line segments measured with AutoCAD ${ }^{\circledR}$ had also higher inter-rater reliability with the lowest absolute variability compared with the other software packages. Inter-rater reliability was similar for measurements performed with ImageTool ${ }^{\circledR}$ and Photoshop ${ }^{\circledR}$. Our findings are in agreement with the literature regarding the reliability of measurements made with AutoCAD ${ }^{\circledR}$, a software package commonly used in engineering and that has been found to be useful in the medical field 9 .

Our study revealed that different software packages used for indirect anthropometric measurements may yield significantly different results, meaning that graphic software packages cannot be used indiscriminately. Thus, the graphic software should be chosen judiciously, especially in situations where measurements of the breast are made at two different time points, such as for preand postoperative evaluation.

\section{Conclusion}

There was no agreement between linear measurements made with the three graphic software packages evaluated in this study. Linear measurements made with AutoCAD ${ }^{\circledR}$ were the most precise; those obtained with ImageTool ${ }^{\circledR}$ were the most accurate; and Adobe Photoshop ${ }^{\circledR}$ yielded the least accurate results. Precision and accuracy of angular measurements made with the three software packages were similar.

\section{References}

1. Watmough DJ. Diaphanography: mechanism responsible for the images. Acta Radiol Oncol. 1982;21(1):11-5. PMID: 6283792.

2. Christie D, Sharpley C, Curtis T. Improving the accuracy of a photographic assessment system for breast cosmesis. Clin Oncol ( $R$ Coll Radiol). 2005;17(1):27-31. PMID: 15714926.

3. Ellis H, Colborn GL, Skandalakis JE, Ellis H, Colborn GL, Skandalakis JE. Surgical embryology and anatomy of the breast and its related anatomic structures. Surg Clin North Am. 1993;73(4):61132. PMID: 8378813

4. Hochman B, Nahas FX, Ferreira LM. Photography in medical research. Acta Cir Bras. 2005;20(Suppl 2):19-25. PMID: 16283023.

5. Quieregatto PR, Hochman B, Ferrara SF, Furtado F, Liebano RE, Sabino Neto M, Ferreira LM. Anthropometry of the breast region: 
how to measure? Aesthetic Plast Surg. 2014;38(2):344-9. doi: 10.1007/s00266-014-0291-9.

6. Ward CM. An analysis, from photographs, of the results of four approaches to elongating the columella after repair of bilateral cleft lip. Plast Reconstr Surg. 1979;64(1):68-76. PMID: 377332.

7. Nechala P, Mahoney J, Farkas LG. Digital two-dimensional photogrammetry: a comparison of three techniques of obtaining digital photographs. Plast Reconstr Surg. 1999;103(7):1819-25. PMID: 10359240.

8. Sivagnanavel V, Smith RT, Lau GB, Chan J, Donaldson C, Chong NV. An interinstitutional comparative study and validation of computer aided drusen quantification. Br J Ophthalmol. 2005;89(5):554-7. PMID: 15834083.

9. Assunção WG, Gomes EA, Tabata LF, Gennari-Filho H. A comparison of profilometer and AutoCAD software techniques in Evaluation of implant angulation in vitro. Int J Oral Maxillofac Implants. 2008;23(4):618-22. PMID: 18807556.

10. Penn J. Breast reduction. Br J Plast Surg. 1955;7(4):357-71. PMID: 13230442

11. Smith DJ Jr, Palin WE Jr, Katch VL, Bennett JE. Breast volume and anthropomorphic measurements: normal values. Plast Reconstr Surg. 1986;78(3):331-5. PMID: 3737757.

12. Smith DJ Jr, Palin WE Jr, Katch V, Bennett JE. Surgical treatment of congenital breast asymmetry. Ann Plast Surg. 1986;17(2):92-101. PMID: 3273092.

13. Malata CM, Boot JC, Bradbury ET, Ramli AR, Sharpe DT. Congenital breast asymmetry: subjective and objective assessment. Br J Plast Surg. 1994;47(2):95-102. PMID: 8149066.

14. Westreich M. Anthropomorphic breast measurement: protocol and results in 50 women with aesthetically perfect breasts and clinical application. Plast Reconstr Surg. 1997;100(2):468-79. PMID: 9252618

15. Brown TP, Ringrose C, Hyland RE, Cole AA, Brotherston TM. A method of assessing female breast morphometry and its clinical application. Br J Plast Surg. 1999;52(5):355-9. PMID: 10618977.

16. Odo LM, Guimarães PA, Silva AL, Sabino Neto M, Ferreira LM. Assessing the outcome of surgical treatment of breast asymmetry by means of linear measures. Arq Catarinenses Med. 2009;38(Suppl 1):43-5.

17. Pozzobon AV, Sabino Neto M, Veiga DF, Abla LE, Pereira JB, Biasi TL, Ferreira LM, Yamashita LA, Kawano F, Nakano EM, Shigueoka DC. Magnetic resonance images and linear measurements in the surgical treatment of breast asymmetry. Aesthetic Plast Surg. 2009;33(2):196-203. doi: 10.1007/s00266-008-9224-9.
18. Agbenorku P, Agbenorku M, Iddi A, Amevor E, Sefenu R, Osei D. Measurements of breasts of young West African females: a guideline in anatomical landmarks for adolescent breast surgery. Aesthetic Plast Surg. 2011;35(1):49-54. doi: 10.1007/s00266-010-9555-1.

19. Sacchini V, Luini A, Tana S, Lozza L, Galimberti V, Merson M, Agresti R, Veronesi P, Greco M. Quantitative and qualitative cosmetic evaluation after conservative treatment for breast cancer. Eur J Cancer. 1991;27(11):1395-400. PMID: 1835855.

20. Mallucci P, Branford OA. Concepts in aesthetic breast dimensions: analysis of the ideal breast. J Plast Reconstr Aesthet Surg. 2012;65(1):8-16. doi: 10.1016/j.bjps.2011.08.006.

21. Kouchi M, Mochimaru M, Tsuzuki K, Yokoi T. Random errors in anthropometry. J Hum Ergol (Tokyo). 1996;25(2):155-66. PMID: 9735595 .

\section{Correspondence:}

Miguel Sabino Neto

Disciplina de Cirurgia Plástica-UNIFESP

Rua Napoleão de Barros, $715 / 4^{\circ}$ andar

04023-002 São Paulo - SP Brasil

Tel.: (55 11)5576-4118

Fax: (55 11)5539-0824

msabino@uol.com.br

Received: May 19, 2014

Review: July 18, 2014

Accepted: Aug 22, 2014

Conflict of interest: none

Financial source: none

${ }^{1}$ Research performed at Division of Plastic Surgery, Department of Surgery, Federal University of Sao Paulo (UNIFESP), Brazil. Part of Master degree thesis, Postgraduate Program in Plastic Surgery. Tutor: Bernardo Hochman in memorian. 